\title{
MENINGKATKAN KEMAMPUAN SISWA DALAM PEMECAHAN MASALAH MATEMATIK MELALUI PENDEKATAN METAKOGNITIF
}

\author{
Oleh: Dr. Nanang, M.Pd.
}

\begin{abstract}
Abstrak :
Penelitian eksperimen ini bertujuan untuk mengetahui peningkatan dan membandingkan kemampuan pemecahan masalah matematik pada kelompok siswa yang pembelajarannya menerapkan pendekatan metakognitif (PM) dan pendekatan konvensional (PK). Instrumen yang digunakan berupa tes kemampuan pemecahan masalah matematik. Analisis data dilakukan dengan uji gain ternormalisasi dan uji perbedaan dua rata-rata. Hasil utama dari penelitian ini adalah secara keseluruhan siswa yang pembelajarannya dengan PM (kelompok eksperimen) peningkatan kemampuan pemecahan masalah matematiknya termasuk tinggi dan secara signifikan lebih baik dibandingkan dengan siswa yang pembelajarannya dengan PK (kelompok kontrol).
\end{abstract}

Kata Kunci: Pemecahan masalah, matematik, metakognitif.

\section{Pendahuluan}

Hasil temuan Wahyudin (1999), guru matematika pada umumnya mengajar dengan metode ceramah dan ekspositori. Pada kondisi seperti itu, kesempatan siswa untuk menemukan dan membangun pengetahuannya sendiri hampir tidak ada. Sebagian besar siswa tampak mengikuti dengan baik setiap penjelasan atau informasi dari guru, siswa jarang mengajukan pertanyaan pada guru sehingga guru aktif sendiri menjelaskan apa yang telah disiapkannya, siswa hanya menerima saja apa yang disampaikan oleh guru.

Jika kondisi di atas masih terjadi pada saat sekarang, yaitu jika guru matematika pada umumnya mengajar dengan metode ceramah dan ekspositori, maka ada kemungkinan hal ini merupakan salah satu penyebab siswa lemah dalam matematika, yaitu kurang memiliki kemampuan pemahaman untuk mengenali konsep-konsep dasar matematika (aksiomatik, definisi, kaidah, dan teorema) yang berkaitan dengan pokok bahasan yang sedang dibicarakan.

Kemampuan pemahaman matematik menurut Sumarmo (2003) diperlukan untuk menyelesaikan masalah matematika, masalah dalam disiplin ilmu lain, dan masalah dalam kehidupan sehari-hari, yang merupakan visi pengembangan pembelajaran matematika untuk memenuhi kebutuhan masa kini. Untuk mengkondisikan siswa memiliki kemampuan pemecahan masalah matematik, guru dalam mengajarnya agar mengkondisikan siswa untuk berpikir pada diri mereka sendiri untuk menggunakan konteks dalam belajar dan menyelesaikan permasalahan matematika. Hal ini diharapkan dapat mengatasi salah satu faktor rendahnya kemampuan pemecahan masalah (problem solving).

Dalam pembelajaran matematika, kemampuan pemecahan masalah sangatlah penting. Hal ini sesuai dengan pendapat Branca (Krulik dan Reys, 1980:3), yaitu 1) bahwa kemampuan pemecahan masalah merupakan tujuan umum pembelajaran matematika, bahkan sebagai jantungnya matematika, 2) pemecahan masalah dapat meliputi metode, prosedur dan strategi atau cara yang digunakan merupakan proses inti dan utama dalam kurikulum matematika, dan 3) pemecahan masalah merupakan kemampuan dasar dalam belajar 
matematika. Sehingga dapat dikatakan kemampuan pemecahan masalah dalam matematika merupakan hal yang sangat penting untuk dimiliki oleh seorang siswa dan juga merupakan salah satu faktor yang menentukan hasil belajar matematika siswa.

Menurut Schoenfeld (1992), salah satu model pembelajaran yang dilandasi kontruktivisme dalam upaya meningkatkan proses kemampuan pemecahan masalah siswa yang dapat mengedepankan bagaimana seharusnya siswa berpikir, dan bagaimana berpikir terbaik untuk dapat memecahkan permasalahan matematika adalah model pembelajaran keterampilan metakognitif.

Dalam pembelajaran keterampilan metakognitif guru berperan sebagai pembimbing, dinamisator, motivator, dan fasilitator. Sedangkan dalam memilih strategi untuk memecahkan masalah, dapat digunakan langkah-langkah seperti yang dianjurkan Polya (Ruseffendi, 1991), yaitu: (1) memahami persoalan, (2) membuat rencana atau cara untuk menyelesaikannya, (3) menjalankan rencana sesuai rencana yang dibuat pada langkah kedua, dan (4) melihat kembali jawaban yang telah diperoleh.

Berdasarkan kutipan di atas, tampak bahwa kemampuan pemecahan masalah siswa dalam pembelajaran matematika dibutuhkan dalam pemecahan masalah matematik. Sedangkan salah satu strategi pembelajaran yang dapat digunakan adalah strategi pembelajaran metakognitif. Berkaitan dengan hal tersebut, penulis terdorong untuk menerapkan pendekatan metakognitif (PM) serta menelaah pengaruhnya terhadap kemampuan siswa dalam pemecahan masalah matematik. Namun demikian timbul pertanyaan pada diri penulis yang dirumuskan dalam masalah penelitian sebagai berikut.

1. Bagaimana peningkatan kemampuan pemecahan masalah matematik siswa yang mendapatkan PM?

2. Apakah peningkatan kemampuan pemecahan masalah matematik siswa yang mendapatkan PM lebih baik dibandingkan dengan yang mendapatkan PK?

\section{Tinjauan Pustaka}

\section{Pemecahan Masalah Matematik}

Menurut Hayes dan Mayer

(Matlin, 1994), masalah (problem) merupakan suatu kesenjangan antara keadaan sekarang dengan tujuan yang ingin dicapai, sementara kita tidak mengetahui apa yang harus dikerjakan untuk mencapai tujuan tersebut. Dengan demikian, masalah dapat diartikan sebagai pertanyaan yang harus dijawab pada saat itu, sedangkan kita tidak mempunyai rencana untuk memperoleh solusi yang jelas. Sedangkan Kantowski (1981) berpendapat bahwa suatu situasi tertentu dapat merupakan masalah bagi orang tertentu, tetapi belum tentu merupakan masalah bagi orang lain.

Merujuk pada pendapat di atas tentang masalah, dapat ditarik kesimpulan bahwa yang dimaksud dengan masalah bagi seseorang adalah suatu situasi yang sesuai dengan tahap perkembangan mentalnya, memiliki pengetahuan prasyarat tentang situasi tersebut dan dapat menyelesaikan tanpa menggunakan algoritma yang rutin. Suatu situasi mungkin merupakan masalah bagi seseorang, namun belum tentu menjadi masalah bagi orang lain. Atau dapat pula diartikan bahwa sesuatu merupakan masalah bagi seseorang apabila orang tersebut ingin mencapai suatu tujuan tertentu tetapi untuk mencapai tujuan itu tidak mudah, memerlukan pemikiran untuk memperoleh solusi (solusi tidak serta merta bisa di dapat), tetapi harus berpikir bagaimana cara mencapai tujuan tersebut.

Dilihat dari strukturnya, Matlin (1994) menyatakan bahwa masalah dapat dibedakan menjadi masalah yang terdefinisi dengan baik (well-defined problem) dan tidak terdefinisi dengan baik atau tidak lengkap (ill-defined problem). Masalah yang terdefinisi dengan baik adalah situasi masalah yang pernyataan asli, tujuan dan aturanaturannya terspesifikasi, sedangkan 
masalah yang tidak terdefinisi dengan baik sebaliknya yaitu pernyataan asal, tujuan dan aturan tidak jelas sehingga tidak memiliki cara sistematik untuk menemukan solusi.

Pemecahan masalah dalam pembelajaran matematika merupakan salah satu aspek utama dari daya matematik (mathematical power) yang direkomendasikan oleh National Council of Teachers of Mathematics (NCTM) tahun 2000 dalam Principles and Standard for School Mathematics untuk dimiliki oleh siswa di semua jenjang.

Pemecahan masalah matematik menurut Polya (Silver, 1997) adalah suatu cara untuk menyelesaikan masalah matematika dengan menggunakan penalaran matematika (konsep matematika) yang telah dikuasai sebelumnya. Ketika siswa menggunakan kerja intelektual dalam pelajaran, pemecahan masalah yang diarahkan sendiri untuk diselesaikan merupakan suatu karakteristik penting. Sabandar (2007:29) mengungkapkan bahwa situasi pemecahan masalah merupakan tantangan dan saat kritis bagi siswa dalam upaya mencari solusi.

Merujuk dari pendapat di atas, tampak bahwa pemecahan masalah merupakan kegiatan yang sangat sulit baik mengajarkannya maupun mempelajarinya. Dalam pemecahan masalah dibutuhkan daya nalar, siswa dituntut untuk dapat memprediksi solusinya, serta cara untuk mendapatkan solusi tersebut dengan berbagai cara, dan harus membuktikan bahwa solusi yang didapat adalah benar. Hal ini tampak dari kenyataan bahwa baik guru maupun siswa berdasarkan hasil survey Suryadi, dkk. (Suherman, dkk., 2001) banyak yang mengalami kesulitan dalam melakukan pemecahan masalah matematik. Demikian pula berdasarkan hasil survey TIMSS tahun 2003 (Herman, 2007) kemampuan siswa Indonesia kelas VIII dalam hal memecahkan masalah matematis masih lemah.

Melihat keadaan seperti ini, perlu kiranya ada upaya melalui pendekatan pembelajaran untuk meningkatkan kemampuan siswa dalam memecahkan masalah matematis. Hal ini dikarenakan dalam Kurikulum Tingkat Satuan Pendidikan Matematika SMP dan Badan Standar Nasional Pendidikan (2006), Pemecahan masalah merupakan fokus dalam pembelajaran matematika.

Dalam memilih strategi pada pemecahan masalah, kita tidak terlepas dari kontribusi ahli matematik Polya (Biryukov, 2003:2) yaitu:

a. Pemahaman masalah. Mengidentifikasi masalah untuk menentukan apa yang diketahui dan apa yang ditanyakan dari setiap aspek permasalahannya.

b. Pemikiran suatu rencana. Menemukan hubungan antara kondisi dan yang ditanyakan.

c. Menyelesaikan masalah.

Menyelesaikan rencana yang kita buat dalam menyelesaikan masalah.

d. Melihat kembali. Memeriksa jawaban yang telah kita peroleh dan melihat kembali langkah-langkah yang telah kita lakukan.

Krulik dan Rudnick (Sabandar, 2007) mengatakan bahwa pada heuristic terakhir dari Polya yaitu melihat kembali (looking back) hanya menguji jawab dan menggunakan hasil yang diperoleh untuk menyelesaikan soal lain. Dalam mencari solusi, siswa sudah harus berpikir kritis dan kreatif. Namun, jika mereka berhenti ketika jawaban ditemukan, maka mereka kehilangan saat yang berharga dalam proses belajar yang sedang mereka jalani. Dengan kerja keras mereka membangun rancangan serta memilih beragam strategi untuk menyelesaikan soal. Oleh karena pada saat menyelesaikan soal itu mereka sedang termotivasi kemudian senang dengan hasil yang dicapai, maka rasa senang dan termotivasi ini harus tetap dipertahankan, dengan memberikan tugas baru kepada siswa, yaitu: "Menyelesaikan soal itu dengan cara yang lain", "Mengajukan pertanyaan ... 
bagaimana jika”, "Apa yang salah", dan "Apa yang akan kamu lakukan”.

\section{Pendekatan Metakognitif}

Metakognitif merupakan kata sifat dari metakognisi (metacognition) dengan prefik "meta" dan kata "kognisi". Meta berasal dari bahasa Yunani yang berarti "setelah", "melebihi", atau "di atas". Secara umum kognisi diartikan sebagai apa yang diketahui serta dipikirkan oleh seseorang. Pengertian metakognitif oleh Matlin (1994) diartikan sebagai keterampilan kompleks. Metakognitif dibutuhkan siswa untuk menguasai suatu jangkauan keterampilan intelektual khusus, kemudian mengumpulkan kembali keterampilan-keterampilan ini ke dalam strategi belajar yang tepat untuk satu masalah khusus atau isu-isu dalam konteks yang berbeda.

Dalam rangka mengembangkan pembelajaran agar tidak membosankan dan lebih bermakna diperlukan kreativitas guru di dalam membawakan materi yang disampaikan. Pembelajaran bermakna ditunjang oleh metode dan pendekatan yang dipilih guru dalam menyampaikan materinya. Dalam pembelajaran yang mengembangkan kemampuan pemecahan masalah, banyak hal yang dapat dilakukan diantaranya adalah dengan pemilihan model atau pendekatan pembelajaran yang akan digunakan sehingga mampu mengaktifkan siswa dalam proses berpikirnya.

Menurut Schoenfeld (1992), salah satu pendekatan pembelajaran yang dilandasi oleh konstruktivisme dalam upaya meningkatkan proses kemampuan pemecahan masalah siswa yang dapat mengedepankan bagaimana seharusnya siswa berpikir, dan bagaimana berpikir terbaik untuk dapat memecahkan permasalahan matematika, sehingga menjadikan siswa yang lebih aktif dan kreatif dalam belajar adalah pendekatan pembelajaran metakognitif. Pandangan mengenai pendekatan metakognitif dalam pembelajaran ini telah dinyatakan oleh Meyer (Muin, 2005) bahwa pembelajaran melalui upaya penyadaran kognisi siswa merupakan pembelajaran dengan pendekatan metakognitif.
Berkaitan dengan penelitian metakognitif, El-Emam (1999:166) membuat program pembelajaran yang bertujuan untuk membantu siswa calon guru matematika meningkatkan perilakuperilaku metakognitif dalam pemecahan masalah adalah sebagai berikut:

\begin{tabular}{llr}
\multicolumn{1}{c}{ Tahap } & $\begin{array}{l}\text { Persiapan. } \\
\text { diberikan }\end{array}$ & Pengajaran \\
langsung & untuk \\
memperkenalkan & partisipan terhadap \\
strategi-strategi & metakognitif dan
\end{tabular}
pemecahan masalah secara heuristik.

a. Tahap Pemecahan Masalah. Partisipan terlibat dalam memecahkan beragam masalah matematika tidak rutin. Mereka mempraktekkan penggunaan strategi-strategi kognitif dan metakognitif dalam pemecahan masalah.

b. Tahap Refleksi. Partisipan didorong untuk: 1) Merefleksikan apa yang telah mereka pelajari, 2) Menjelaskan bagaimana menggunakan strategistrategi spesifik untuk memecahkan masalah-masalah tertentu, 3) Mencontohkan peran guru dalam pembelajaran pemecahan masalah berbasis metakognisi.

Berdasarkan kutipan di atas, tampak bahwa menumbuhkan pengalaman metakognisi adalah penting. Pada saat seseorang memiliki pengalaman metakognisi dan mengetahui bagaimana menerapkan pengalaman tersebut, akan memiliki peluang lebih tinggi untuk dapat menyelesaikan masalah. Hal ini dikarenakan pembelajaran melalui pendekatan metakognitif mendesain model pembelajaran yang mengintegrasikan pertanyaan-pertanyaan yang bersifat metakognitif berkaitan dengan topik yang dipelajari serta pengontrolan terhadap proses berpikir di dalam pembelajaran. Pertanyaan-pertanyaan metakognitif diintegrasikan ke dalam bahan ajar secara tertulis dan atau secara langsung melalui lisan untuk menumbuhkan keyakinan dan kesadaran terhadap konsep dan prinsip matematika 
yang dipelajari serta melakukan pengontrolan terhadap proses berpikir yang dilakukan. Secara lisan pertanyaan guru merangsang siswa untuk dapat bertanya pada diri sendiri berkaitan dengan topik yang dipelajari.

\section{Hipotesis}

Berdasarkan permasalahan dan kajian pustaka di atas, dalam penelitian ini penulis mengajukan hipotesis sebagai berikut, "Kemampuan pemecahan masalah matematik siswa yang mendapatkan pendekatan metakognitif lebih baik dibandingkan dengan yang mendapatkan pendekatan konvensional".

\section{Metode Penelitian}

Penelitian ini merupakan penelitian eksperimen dengan menerapkan pendekatan metakognitif (PM) dalam pembelajaran matematika. Akan diteliti dampak yang muncul pada subjek penelitian sebagai akibat dari perlakuan pembelajaran yang diterapkan yaitu kemampuan pemecahan masalah matematik.

Kelompok eksperimen diberi perlakuan PM dan kelompok kontrol mendapat pendekatan konvensional (PK). Sebelum pembelajaran diadakan pretes dan sesudah pembelajaran diadakan postes kemampuan pemecahan masalah matematik. Menurut Ruseffendi (1994: 46) desain kelompok kontrol pretes-postes yang sesuai dengan kondisi tersebut adalah seperti berikut.

$$
\begin{array}{llll}
\text { A } & \text { O } & \text { X } & \text { O } \\
\text { A } & \text { O } & & \text { O }
\end{array}
$$

Keterangan:

X: Pendekatan PM; O: Pretes atau Postes; A: Pengelompokan subjek secara acak

Populasi dalam penelitian ini adalah siswa Sekolah Menengah Pertama (SMP). Teknik sampling dalam penelitian ini ditentukan dengan teknik stratified random sampling (teknik strata). Pengambilan sampel dilakukan dengan dua langkah. Pertama, memilih secara acak satu sekolah (terpilih SMP Negeri 3 Garut). Kedua, memilih secara acak dua Kelas VIII yang paralel pada sekolah tersebut, untuk ditetapkan sebagai kelas Eksperimen dan kelas kontrol.
Untuk memperoleh data yang diperlukan dalam penelitian ini, digunakan jenis instrumen tes pemecahan masalah matematik. Materi yang diteskan meliputi keliling lingkaran, luas daerah lingkaran, sudut pusat dan sudut keliling lingkaran, serta hubungan sudut pusat, panjang busur, dan luas juring. Soal ini berbentuk uraian sebanyak 5 soal, pelaksanaan tes terdiri dari pre-test dan post-test.

Sebelum digunakan, soal pemecahan masalah matematik tersebut divalidasi untuk melihat validitas isi dan validitas muka, kemudian diujicobakan secara empiris. Tujuan ujicoba empiris ini untuk mengetahui tingkat reliabilitas seperangkat soal tes dan validitas butir soal. Untuk mengukur validasi muka, pertimbangan didasarkan pada: kejelasan bahasa/ redaksional, kejelasan gambar/representasi. Sedangkan untuk mengukur validasi isi, pertimbangan didasarkan pada: materi pokok yang diberikan, tujuan yang ingin dicapai, aspek kemampuan yang diukur, tingkat kesukaran untuk siswa Kelas VIII semester 2 .

Untuk memperoleh data kemampuan pemecahan masalah matematik, dilakukan penskoran terhadap jawaban siswa untuk setiap butir soal. Kriteria penskoran setiap soal adalah 4 apabila jawaban benar, sedangkan skor idealnya adalah: 5 soal x $4=20$.

Data yang diperoleh dari skor kemampuan pemecahan masalah matematik dikelompokkan menurut kelompok pendekatan pembelajaran (PM dan PK). Pengolahan data diawali dengan menguji peningkatan dengan gain ternormalisasi. Selanjutnya dilakukan uji perbedaan dua rata-rata dengan uji-t, yang diawali dengan menuguji persyaratan statistik yang diperlukan sebagai dasar dalam pengujian hipotesis antara lain uji normalitas dan homogenitas. Seluruh perhitungan 
statistik menggunakan bantuan komputer program SPSS 16.

\section{Hasil Penelitian Dan Pembahasan}

Untuk mengetahui sejauh mana peningkatan kemampuan pemecahan masalah matematik siswa yang mendapatkan PM, digunakan uji gain ternormalisasi menurut Meltzer (2002) dengan gain ternormalisasi $(\mathrm{g})$ :

$$
g=\frac{\text { Skor postes }- \text { Skor pretes }}{\text { Skor ideal }- \text { Skor pretes }}
$$

Kategori gain ternormalisasi (g) adalah: $\mathrm{g}<0,3$ : rendah; $0,3 \leq \mathrm{g}<0,7$ : sedang; $0,7 \leq \mathrm{g}$ : tinggi. Berdasarkan hasil analisis data penelitian, diperoleh data yang disajikan pada Tabel 1 sebagai berikut.

Tabel 1. Peningkatan Kemampuan Pemecahan Masalah Matematik Siswa
\begin{tabular}{|c|c|c|c|c|c|}
\hline $\begin{array}{c}\text { Kumlah } \\
\text { Subjek }\end{array}$ & $\begin{array}{c}\text { Rerata } \\
\text { Postes }\end{array}$ & $\begin{array}{c}\text { Rerata } \\
\text { Pretes }\end{array}$ & Rerata Gain & $\begin{array}{c}\text { Rerata Gain } \\
\text { Ternormalisasi }\end{array}$ & Kriteria \\
\hline \hline 44 & 16,4 & 2,2 & 14.3636 & 0,798 & Tinggi \\
\hline
\end{tabular}

Keterangan: Skor Ideal 20.

Pada Tabel 1, diperoleh rerata gain ternormalisasi $(\mathrm{g})=0,798$ dengan kriteria tinggi. Hal ini berarti peningkatan kemampuan pemecahan masalah matematik siswa-siswa yang mendapatkan PM rata-rata termasuk tinggi.

Dari Tabel 1 juga diperoleh informasi bahwa kelompok siswa yang mendapatkan PM, kemampuan pemecahan masalah matematiknya berdasarkan pada prosentase skor rerata dari skor ideal $(\mathrm{P})=$ $\frac{16,4}{20} \times 100 \%=82 \% \quad$ termasuk baik berdasarkan kriteria sebagai berikut.

\begin{tabular}{|l|l|l|l|}
\hline & $\mathrm{P}$ & $\geq 80 \%:$ & Siswa berkemampuan baik \\
\hline $60 \% \leq$ & $\mathrm{P}$ & $<80 \%:$ & Siswa berkemampuan cukup \\
\hline & $\mathrm{P}$ & $<60 \%:$ & Siswa berkemampuan kurang \\
\hline
\end{tabular}

Data penelitian yang berkenaan dengan kemampuan pemecahan matematik diperoleh melalui tes awal dan tes akhir. Rerata gain yang merupakan gambaran sementara peningkatan kemampuan pemecahan matematik baik dengan pendekatan PM maupun PK disajikan pada Tabel 2.

Tabel 2. Deskrifsi Statistik Data Kemampuan Pemecahan Matematik

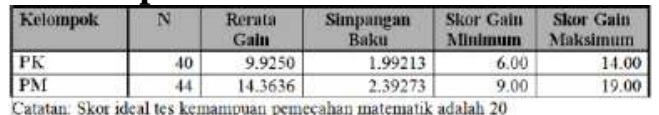

Tabel 2 memberikan gambaran bahwa skor rerata gain siswa kelompok PM lebih tinggi dibandingkan dengan kelompok PK. Untuk mengetahui ada atau tidak adanya perbedaan rerata gain kemampuan pemecahan masalah matematik yang signifikan, selanjutnya digunakan analisis statistik melalui uji hipotesis melalui langkah-langkah sebagai berikut.

1. Uji Normalitas Distribusi Data

Hipotesis nol (Ho) yang diuji melawan hipotesis alternatif $\mathrm{Ha}$ adalah sebagai berikut.

Ho: Sampel berdistribusi normal Ha: Sampel tidak berdistribusi normal Kriteria pengujian: jika nilai probabilitas (sig) dari Z lebih besar dari $\alpha=0,05$, maka Ho diterima. Rangkuman hasil perhitungan uji normalitas disajikan pada Tabel 3.

Tabel 3. Uji Normalitas Skor Gain Kemampuan Pemecahan Matematik

\begin{tabular}{|c|c|c|c|c|}
\hline Pendekatan & $\mathrm{N}$ & K S Z & Sig. (2 tailed) & Ho \\
\hline PMI & 44 & 1.305 & 0,474 & Terima \\
\hline PK & 40 & 0.886 & 0.066 & Terima \\
\hline
\end{tabular}

Pada Tabel 3 terlihat bahwa nilai probabilitas (Sig.) untuk setiap pendekatan lebih besar dari $\alpha=0,05$, ini berarti Ho diterima. Dengan demikian, data skor gain kemampuan pemecahan matematik untuk setiap kelompok berdistribusi normal.

2. Uji Homogenitas Dua Varians

Karena semua kelompok data berdistribusi normal, maka selanjutnya dilakukan uji homogenitas varians populasi dari skor kemampuan pemecahan matematik berdasarkan kelompok pembelajaran dengan 
menggunakan uji Levene. Hipotesis nol (Ho) yang diuji melawan hipotesis alternatif $\mathrm{Ha}$ adalah sebagai berikut.

Ho:Tidak terdapat perbedaan variansi dari setiap kelompok data

Ha:Paling tidak ada satu kelompok yang variansinya berbeda dari yang

Lainnya

Kriteria pengujian: jika nilai probabilitas (sig) dari Z lebih besar dari $\alpha=$ 0,05, maka Ho diterima. Rangkuman hasil perhitungan uji homogenitas varians populasi disajikan pada Tabel 4.

Tabel 4. Uji Homogenitas Dua Varians Skor Gain

\begin{tabular}{|c|c|c|c|c|}
\hline Levente Statistic ( F) & dfI & $\mathrm{df} 2$ & Sig. & $\mathrm{Ho}$ \\
\hline
\end{tabular}

\begin{tabular}{|l|l|c|c|c|}
\hline 0.610 & 43 & 39 & 0.437 & Terima \\
\hline
\end{tabular}

Pada Tabel 4 terlihat bahwa nilai probabilitas (sig.) $=0,437$ lebih besar dari $\alpha=0,05$, ini berarti hipotesis nol (Ho) diterima.

3. Uji Perbedaan Dua Rata-rata

Selanjutnya, untuk mengetahui ada atau tidak adanya perbedaan rerata gain kedua kelompok data berdasarkan pendekatan pembelajaran digunakan uji-t. Rangkuman hasil uji-t disajikan pada Tabel 5.

\begin{tabular}{|c|c|c|c|c|c|c|}
\hline \multicolumn{7}{|c|}{ Tabel 5. Rekapitulasi Uji Perbedaan Kemampuan Pemecahan Matematik } \\
\hline t & df & $\begin{array}{c}\text { Sig. } \\
\text { (2tailed) }\end{array}$ & $\begin{array}{c}\text { Mean } \\
\text { Difference }\end{array}$ & $\begin{array}{c}\text { Std. Error } \\
\text { Difference }\end{array}$ & $\begin{array}{c}\mathbf{9 5 \%} \text { Confidence Interval of } \\
\text { the Difference }\end{array}$ \\
\cline { 6 - 7 } & & & & Lower & Lpper \\
\hline-9.188 & 82 & 0.000 & -4.43864 & 0.48309 & -5.39965 & -3.47762 \\
\hline
\end{tabular}

Hipotesis yang diuji adalah:

Ho: Tidak terdapat perbedaan kemampuan pemecahan matematik antara siswa yang mendapatkan PM dengan PK

Ha: Terdapat perbedaan kemampuan pemecahan matematik antara siswa yang mendapatkan PM dengan PV

Dari hasil uji-t pada Tabel 5 diperoleh nilai $\mathrm{t}=-9,188$ dengan nilai probabilitas (sig.) $=0,000$. Oleh karena nilai probabilitas (sig.) lebih kecil dari $\alpha=0,05$, maka hipotesis nol (Ho) ditolak. Hal ini berarti terdapat perbedaan kemampuan pemecahan matematik antara siswa-siswa yang mendapatkan PM dengan PK.

Untuk mengetahui rerata gain mana yang berbeda secara signifikan dalam kemampuan pemecahan matematik, dilanjutkan dengan uji Scheffe, hasil perhitungannya disajikan pada Tabel 6.
Tabel 6. Uji Scheffe Skor Rerata Gain Kemampuan Pemecahan Matematik

\begin{tabular}{|c|c|c|c|c|c|}
\hline $\begin{array}{c}\text { (I) } \\
\text { Pendekatan }\end{array}$ & $\begin{array}{c}\text { (J) } \\
\text { Pendekatan }\end{array}$ & $\begin{array}{c}\text { Perbedaan Rerata } \\
\text { (I-J) }\end{array}$ & $\begin{array}{c}\text { Std. } \\
\text { Error }\end{array}$ & Sig. & Ho \\
\hline PK & PM & -4.43864 & 0.48309 & 0.000 & Tolak \\
\hline
\end{tabular}

Pada Tabel 6 terlihat bahwa nilai probabilitas (sig.) untuk pasangan pendekatan pembelajaran lebih kecil dari $\alpha=0,05$, maka dapat ditarik kesimpulan bahwa kemampuan pemecahan matematik siswa yang memperoleh pendekatan PM secara signifikan lebih baik dibandingkan dengan siswa yang memperoleh pendekatan PK.

\section{Penutup}

\section{Simpulan}

Berdasarkan hasil analisis, temuan, dan pembahasan yang telah dikemukakan pada bagian sebelumnya, diperoleh kesimpulan sebagai berikut.

a. Peningkatan kemampuan pemecahan masalah matematik kelompok siswa yang mendapatkan PM berada pada klasifikasi tinggi.

b. Kemampuan pemecahan masalah matematik siswa yang mendapatkan PM secara signifikan lebih baik dibandingkan dengan yang mendapatkan PK.

\section{Saran}

Berdasarkan kesimpulan di atas, peneliti mengusulkan beberapa saran sebagai berikut.

a. Pendekatan metakognitif hendaknya terus dikembangkan dan dijadikan sebagai alternatif pilihan guru dalam pembelajaran matematika sehari-hari.

b. Dengan memperhatikan temuan bahwa pendekatan metakognitif berhasil dapat meningkatkan kemampuan pemecahan masalah matematik siswa, maka diharapkan penerapan pendekatan metakognitif menjadi bahan masukkan bagi pengambil kebijakan untuk mengembangkan potensi kemampuan pemecahan masalah matematik. 


\section{Daftar Pustaka}

Badan Standar Nasional Pendidikan (2006). Standar Kompetensi dan Kompetensi Dasar Matematika SMA/MA. Jakarta: Departemen Pendidikan Nasional.

Biryukov, P. (2003). Metacognitive Aspects of Solving Combinatorics Problems. Berr-Sheva: Kaye College of Education.

El-Emam, Y.A. (1999). The Effectiveness of an Instructional Program for Promoting Prospective Mathematics Teachers' Use of Metacognitive Strategies in Problem Solving. . [Online]. Tersedia: http://www.math uspin.lt/ qrwin/EELE Man 163172.pdf. [12 Mei 2005].

Herman, T. (2007). Pembelajaran Matematika Berbasis Masalah untuk Meningkatkan Kemampuan Berpikir Kritis dan Kreatif Siswa SMP. Prosiding Seminar Nasional Matematika. 108 - 114. Bandung: UPI.

Kantowski, M.G. (1981). "Problem Solving". Mathematics Education Research: Implications for the 80's. Virginia: NCTM.

Krulik, S. dan Reys, R.E. (1980). Problem Solving in School Mathematics. Virginia: NCTM.

Matlin, MW. (1994). Cognition (third edition). New York: Harcourt Brace Publishers.

Meltzer, D.E. (2002). Addendum to: The Relationship between Mathematics Preparation and Conceptual Learning Gain in Physics: A Possible "Hidden Variable" in Diagnostics Pretest Scores. [Online]. Tersedia: http://www. physics.iastate.edu. [9 Oktober 2009].

Muin, A. (2005). Pendekatan Metakognitif untuk Meningkatkan Kemampuan Matematika Siswa SMA. Tesis pada SPS UPI: Tidak diterbitkan.

NCTM (2000). Principles and Standard for School Mathematics. Reston, VA: NCTM.
Ruseffendi E.T. (1994). Dasar-Dasar Penelitian Pendidikan dan Bidang Non-Eksakta Lainnya. Semarang: IKIP Semarang Press.

Schoenfeld, AH. (1992). „Learning to Think Mathematically: Problem Solving, Metacognition, and Sense Making in Mathematics". Handbook of Research on Mathematics Teaching and Learning. New York: Macmillan Publishing Company.

Silver, E.A. (1997). Fostering Creativity through Instruction Rich in Mathematical Problem Solving and Problem Posing. [Online]. Tersedia:http://66.102.7.104/ search?q=cache:Fw8LgxQoFwJ:www.fizkarlsruhe.de/fiz. [ Oktober 2007].

Suherman, E. dkk. (2001). Strategi Pembelajaran Matematika Kontemporer. Bandung: JICA, FPMIPA UPI.

Sumarmo, U. (1987). Kemampuan Pemahaman dan Penalaran Matematika Siswa SMA Dikaitkan dengan Kemampuan Penalaran Logik Siswa dan Beberapa Unsur Proses BelajarMengajar. Disertasi Doktor pada FPS IKIP Bandung: tidak diterbitkan.

Wahyudin (1999). Kemampuan Guru Matematika, Calon Guru Matematika, dan Siswa dalam Mata Pelajaran Matematika. Disertasi. PPS. UPI: Tidak diterbitkan.

\section{Identitas Penulis}

Dr. Nanang, M.Pd, Dosen Kopertis Wil. IV dpk. STKIP Garut. S-1 Jurusan Pend. Matematika IKIP Bandung lulus tahun 1989, S-2 Jurusan Pend. Matematika IKIP Surabaya lulus tahun 1999, S-3 Jurusan Pendidikan Matematika UPI lulus tahun 2009. 
Mosharafa

Jurnal Pendidikan Matematika

Volume 1, Nomor 1, Mei 2012 